Working Paper No. 32, 2021

The New Brazilian Right and the Public Sphere

Camila Rocha
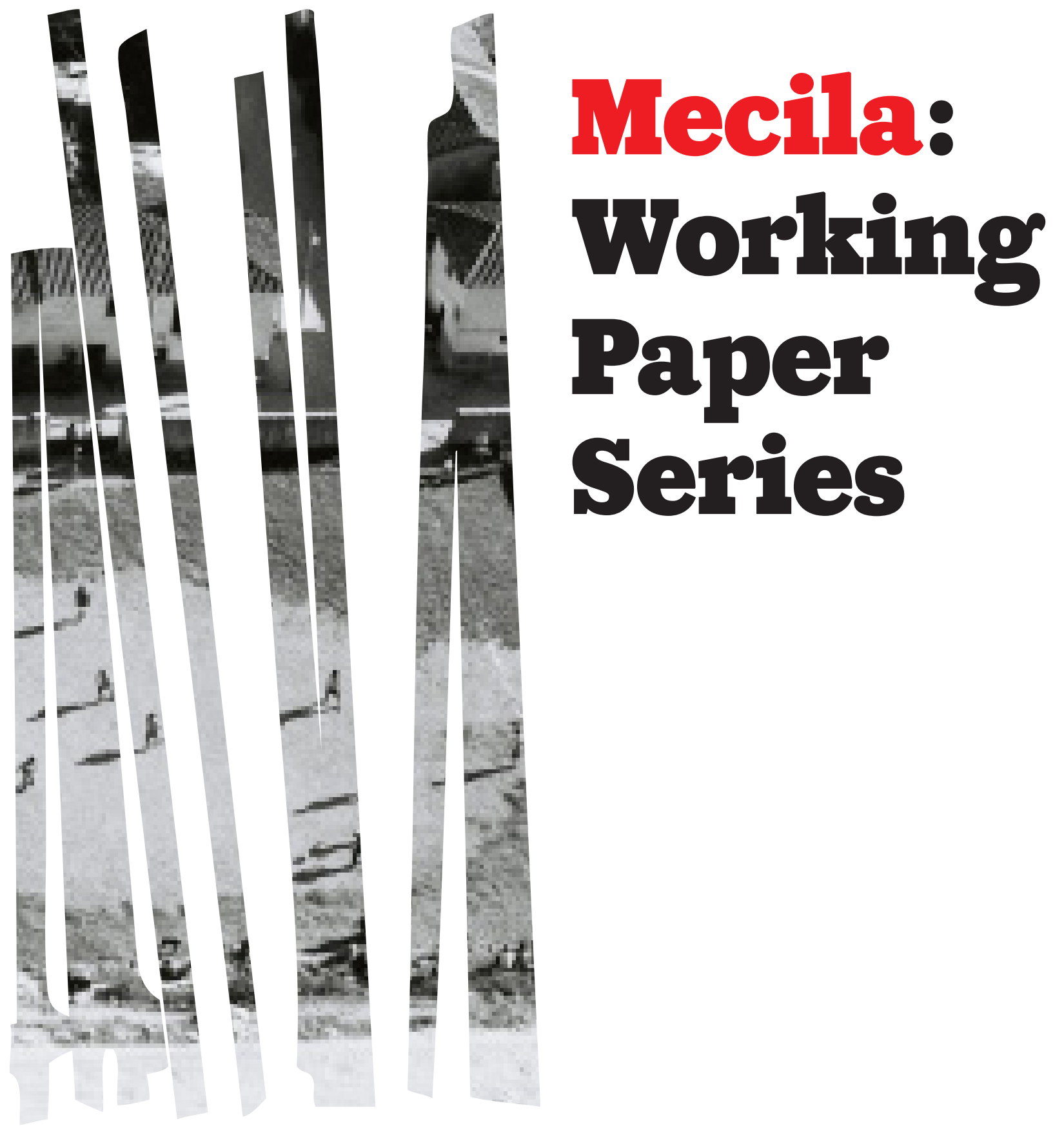

Paper

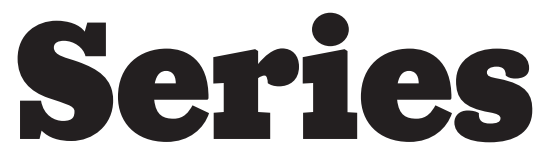


The Mecila Working Paper Series is produced by:

The Maria Sibylla Merian International Centre for Advanced Studies in the Humanities and Social Sciences Conviviality-Inequality in Latin America (Mecila), Rua Morgado de Mateus, 615, São Paulo - SP, CEP 04015-051, Brazil.

Executive Editors: Sérgio Costa, Lateinamerika-Institut, Freie Universität Berlin, Germany Joaquim Toledo Jr., Mecila, São Paulo, Brazil

Editing/Production: Julia Roth, Peter Birle, Joaquim Toledo Jr., Paul Talcott

This working paper series is produced as part of the activities of the Maria Sibylla Merian International Centre for Advanced Studies in the Humanities and Social Sciences ConvivialityInequality in Latin America (Mecila) funded by the German Federal Ministry of Education and Research (BMBF).

All working papers are available free of charge on the Centre website: http://mecila.net

Printing of library and archival copies courtesy of the Ibero-Amerikanisches Institut, Stiftung Preußischer Kulturbesitz, Berlin, Germany.

Citation: Rocha, Camila (2021): "The New Brazilian Right and the Public Sphere", Mecila Working Paper Series, No. 32, São Paulo: The Maria Sibylla Merian International Centre for Advanced Studies in the Humanities and Social Sciences Conviviality-Inequality in Latin America, http://dx.doi.org/10.46877/rocha.2021.32.

Copyright for this edition:

(C) Camila Rocha

This work is provided under a Creative Commons 4.0 Attribution-NonCommercial-NoDerivatives 4.0 International License (CC BY-NC-ND 4.0). The text of the license can be read at https:// creativecommons.org/licenses/by-nc-nd/4.0/legalcode.

The Maria Sibylla Merian International Centre for Advanced Studies in the Humanities and Social Sciences Conviviality-Inequality in Latin America cannot be held responsible for errors or any consequences arising from the use of information contained in this Working Paper; the views and opinions expressed are solely those of the author or authors and do not necessarily reflect those of the Maria Sibylla Merian International Centre for Advanced Studies in the Humanities and Social Sciences Conviviality-Inequality in Latin America, its research projects or sponsors.

Inclusion of a paper in the Mecila Working Paper Series does not constitute publication and should not limit publication (with permission of the copyright holder or holders) in any other venue.

Cover photo: (C) Nicolas Wasser 


\title{
The New Brazilian Right and the Public Sphere
}

Camila Rocha

\begin{abstract}
This paper traces the origins of the New Brazilian Right, regarding the emergence of new leaders, new forms of expression and organization, as well as new sets of ideas, namely libertarianism and anti-globalism. Based on more than thirty in-depth interviews, conducted between 2015 and 2019 with right-wing leaders and activists; on a collection of historical data from right-wing organisations' archives between 2015 and 2018, and on public data, I argue that this phenomenon started in the mid-2000s, after the onset of a corruption scandal related to the Partido dos Trabalhadores (PT) and the dissemination of the pioneering social network Orkut in Brazil. This social network, founded in 2004, preceded Facebook's popularity in Brazil and enabled the creation of alternative and disruptive spaces of debate, referred to here as "counterpublics". By mid- to late 2010s, during the 2014 protests for the impeachment of Dilma Rousseff and Jair Bolsonaro's 2018 presidential campaign, this emerging new right would be at full throttle.
\end{abstract}

Keywords: new Brazilian right | public sphere | counterpublics | Jair Bolsonaro

\section{About the Author:}

Camila Rocha is a political scientist and researcher at the Brazilian Center of Analysis and Planning (CEBRAP), Brazil. Her doctoral thesis, "Menos Marx, Mais Mises": uma gênese da nova direita brasileira (2006-2018), received the 2017-2019 Brazilian Association of Political Science (ABCP) Award for best doctoral thesis in the field. Her research interests are political culture, political behaviour, and qualitative methods. Among her publications are: As direitas nas redes e nas ruas: a crise política no Brasil (with Ester Solano, 2019), and The Brazilian New Right and the election of Jair Bolsonaro (with Ester Solano, forthcoming). 


\section{Contents}

$\begin{array}{ll}\text { 1. Introduction } & 1\end{array}$

2. The Traditional Right: Hayek and the Fight Against Communism 2

3. The New Right: Mises and the Fight Against Globalism 7

4. Breaking with the System: Bolsonaro's Rise to Power 17

5. Conclusion $\quad 24$

6. Bibliography 25 


\section{Introduction}

Years before the ascension of Jair Bolsonaro to power, New Right activism had occupied the Brazilian streets and social networks, taking by surprise political analysts accustomed to associate social movements and street protests with leftist groups. Some claimed that, despite the use of updated activism techniques, the ideas defended by the militants were the same as the ones championed by the country's traditional right: neoliberalism and conservatism. ${ }^{1}$ Thus, it did not make sense to call it a New Right movement. However, despite this continuity of ideas and political actors, it is indeed possible to identify the development of a New Right in Brazil. This process involved the emergence of new leaders and new forms of expression and organization, as well as new ideas that recently started to circulate with greater strength in the Brazilian public sphere: libertarianism and the denunciation of a "leftist cultural hegemony" in the country. ${ }^{2}$

In the first section of this article, I describe right-wing activities in Brazil in the previous decades, considering their links to the actions of the New Right that would emerge years later. In the second and third sections, I indicate how, amid the political transformations

1 Neoliberalism is a set of social, political, and economic ideas and practices whose onset goes back to an attempt to rehabilitate the old laissez-faire, which had acutely decayed after the 1929 crisis. The use of the prefix neo highlights an important change in relation to the 19th century laissez-faire (Boas 2009; Gans-Morse 2009; Jackson 2010). Different from the liberal laissez-faire, neoliberalism defends an active role of the State as a promoter of free markets. In other words, if the State should have no role in regulating the economy for the adepts of laissez-faire, neoliberals believe that the State should act in an active manner in its regulation, in the sense of creating a legal-juridical apparatus to foster the good functioning of the free market (Morresi 2011; Dardot and Laval 2016). It is possible to say that, over the last decades, neoliberalism acquired such importance that, in the words of Pierre Dardot and Christian Laval (Dardot and Laval 2016), it became the world's new zeitgeist. Thus the existence of progressivist neoliberals, such as Bill Clinton and Tony Blair (Fraser 2017), and conservative neoliberals, as Ronald Reagan and Margaret Thatcher. For this reason, considering the arguments developed in this article, it is important to point out the differences between neoliberalism and libertarianism, which came to influence significantly the formation of a New Right in Brazil. Economists Milton Friedman and Friedrich von Hayek can be classified as neoliberals, while it is more adequate to consider Ludwig von Mises as a libertarian, as is proposed by the libertarian journalist Bryan Doherty (Doherty 2007). By contrast, conservatism is not so much a political philosophy as an attitude towards the world that is necessarily reactive to progress in the realm of values and customs. According to the conservative philosopher Roger Scruton (Scruton 2015), due to their denial of abstraction, conservatives tend to "wail" as they try to maintain traditions in view of their impending substitution by something considered worse. This necessity of keeping certain traditions is anchored on the understanding that these are not arbitrary customs, but a condensation of the knowledge originated by a long learning process that favours the reproduction of society. Thus, conservatism can also be described as the feeling of responsibility for the dead, the living and those that are yet to be born, in the formulation of the great critic of the French Revolution Edmund Burke.

2 Libertarianism stands for the radical defence of the free market without any restrictions, and is also associated with the defence of the moral and political liberty of human beings of not being coerced one by another (Doherty 2007). Libertarians usually do not like to be labeled as either left or right. Murray Rothbard's book notwithstanding, empirically they tend to connect with right wing leaders and parties. In Brazil they mostly lean to the right. Although there is a small political group that refers to themselves as left-libertarians, they are gathered under a right-wing party called the New Party (Partido Novo). 
that occurred in the country, a new constellation of actors and ideas had been formed which then greatly contributed to Brazil's political shift to the right.

\section{The Traditional Right: Hayek and the Fight Against Communism}

The existing ties between the leaders of the New Right and those of the traditional Brazilian right were built mainly from the contact network fostered over time by national and international pro-market organizations known as think tanks. ${ }^{3}$ At the end of the 2000s, the circuit of think tanks founded in the 1980s and 1990s expanded, uniting those from anarcho-capitalists to monarchists, and in which older generations of intellectuals and businesspeople met the young militancy that acted on social networks, in student movements, and street protests.

The formation of the first pro-market think tanks in Brazil is intimately related to the dissemination of neoliberalism around the world through the activity of intellectuals, militants, politicians, and business people in the 1930s (Cockett 1995; Stedman-Jones 2014). In Brazil, the promotion of neoliberalism began between the 1940s and the 1950s through a strong campaign against the left that united conservative Catholics and anti-communist businesspeople, who committed themselves to the preservation of private property.

In 1946, Austrian economist F. A. Hayek's The Road of Serfdom, published originally in 1944, was translated into Portuguese with the support of the businessman Adolpho Lindenberg. Lindenberg's intention when contacting Hayek and sponsoring the translation and publication of his book was, in Lindenberg's own words, to "scientifically" make a case for private property and bar the advance of the Catholic left and its main agenda, land reform in the countryside:

Here in Brazil, before the revolution [the 1964 military coup], in the 1950s, there was a leftist, Catholic movement, an important one, which wanted to form communist societies called comunidades de base, [composed of bluecollar workers, priests, feminists, all of them grouped in these communities. [...] And there was another movement, of which I participated, which was called Tradição, família e Propriedade, directed by Plinio Corrêa de Oliveira,

3 In general, think tanks can be defined as permanent organizations, responsible for research and/or diffusion of the ideas related to the proposition of public policies. Considering this, most pro-market think tank activities are classified by the specialized literature as political and ideological advocacy (Desai 1994; Cocket 1995), based particularly on the diffusion of market freedom, sometimes combined with conservative values, and of public policies in accordance with such orientation. In practice, in the words of Mike Caroll, Heritage Foundation's CEO, the business of this type of organization is "people", that is, the gathering of cadres ready to influence and, eventually, act directly in governmental instances. For more information about the operation of think tanks in Brazil after the re-democratization process, see Gros 2003, Casimiro 2010, Hauck 2015, and Rocha 2017. 
a conservative, traditionalist, Catholic movement. From the beginning, we opposed the left-wing movement. Plinio Corrêa de Oliveira wrote a book called Reforma Agrária, questão de consciência because land reform was a motto of the Catholic left. They thought it was possible to divide big properties, make only small properties destroying the Brazilian agrarian structure. [...] At that time, I wrote in a newspaper named O Catolicismo, which had an extraordinary diffusion in the Catholic milieu, showing how the liberal economy is the true one, the one based on natural law and the right to property, and that Catholics have an obligation to fight the left. [...] When I saw the Catholic left advancing too much, I searched for a movement that could beat the left, and I met Hayek, so I got one of his books, got excited, and said: "I am going to publish this to give weight to it, someone respected". I wrote a letter to Hayek, and he authorized me to publish the book, and it was good, you see, because Hayek provides a scientific basis to what we defended. Then [Ludwig von] Mises appeared too, and an American, [Milton] Friedman, these three are the main ones (Interview with Adolpho Lindenberg, March 2017). ${ }^{4}$

Lindenberg, along with Plinio Corrêa de Oliveira (who happened to be Lindenberg's cousin), was one of the main founders of the TFP in 1960, which was intimately related to members of the Brazilian royal family and operated across Latin America. ${ }^{5}$ At the time, there were many groups and organizations committed to the fight against communism (Motta 2002). The appeal of such anti-communist discourse may be observed in the massive adherence to the Marcha da Família com Deus pela Liberdade protests, which, organized by conservative Catholic women, was attended by around 300,000 people in the city of Sao Paulo in 1964 (Cordeiro 2009).

However, if Catholic conservatism captivated a significant share of society at the time, neoliberalism was confined mainly to the elites who, like Lindenberg, were also concerned with what they viewed as substantial advances of the left. Among them, there were Eugenio Gudin, the economist who participated in the 9th meeting promoted by the Mont Pèlerin Society in Princeton, New Jersey, in 1958 (Boianovsky 2018), ${ }^{6}$ and the businessman Paulo Ayres Filho, whose work with the Foundation for Economic

4 I conducted all the interviews mentioned in this chapter for my doctoral thesis about the origins of the Brazilian New Right. For further details on the interviewees see Rocha 2019. The excerpts used here were slightly edited for brevity and fluency.

5 Lindenberg is the acting president of the Instituto Plinio Corrêa de Oliveira (IPCO), founded in December 2006. For more information, see: https://ipco.org.br/quem-somos/\#.W-27UnpKhmA.

6 The Mont Pèlerin Society was founded in 1947 by Hayek with the intention of stimulating the exchange of ideas between intellectuals familiar with the theses outlined in The Road to Serfdom such as Ludwig von Mises, Milton Friedman, Karl Popper, Wilhelm Röpke, Lionel Robbins, Walter Eucken, Walter Lippmann, Michael Polanyi, Salvador de Madariaga, and others (Cocket 1995; StedmanJones 2014). 
Education began in 1959, and who would later join the Mont Pèlerin Society (Spohr 2012) ${ }^{7}$

Ayres Filho was a leading figure in the civil-military coup against President João Goulart in 1964, also backed by Gudin. In 1961, he founded the Instituto de Pesquisa e Estudos Sociais (IPES) in São Paulo, which brought together business people, politicians, military, and intellectuals to resist the advance of the left. ${ }^{8}$ Among those, there were Catholics and conservative intellectuals linked to the Instituto Brasileiro de Filosofia (IBF) and the Sociedade de Convívio. ${ }^{9}$

Although there were neoliberal intellectuals inside IPES, its objective was not to make its ideology known beyond the elite, just as it was not the goal of the economists gathered together in the Associação Nacional de Programação Econômica e Social (ANPES), founded in 1964 by the economist Roberto Campos. Despite being responsible for the visit of foreign economists to Brazil, such as Milton Friedman in 1973, ANPES was exclusively concerned with designing public policies for the country and not with the dissemination of neoliberalism to a wider public (Aranha 2016; Boianovsky 2018), whereas the main aim of IPES was to overthrow João Goulart.

After the military coup in 1964, most of the Brazilian neoliberals supported or participated directly in Marshal Humberto Castelo Branco's administration (1964-1967). Roberto Campos, Minister of Planning of the military government, and Octávio Gouveia de Bulhões, Minister of Finance, were among them. However, with the end of Castelo Branco's mandate and the onset of developmentalist, anti-liberal military governments, the neoliberals lost their recently gained space in the government. In their place, conservative, anti-communist cadres linked to the IBF and the Sociedade de Convívio were appointed to government posts. Since the civil organizations that fostered the neoliberals had shut down, neoliberals started to act on their own in civil society. That

7 The Foundation for Economic Education (FEE) founded in March 1946 in the city of Irvington-onHudson, New York, was idealized by the businessman Leonard Read and was supported for many years by a fund with a multi-million dollar balance, the Volker Fund, created by the magnate William Volker and managed by a free-market enthusiast. Thus, the institution had a relative autonomy in face of immediate political interests and aspired to educate American people for the advantages of free-market capitalism (Doherty 2007).

8 Later, between the 1960s and the 1970s, IPES managed to have branches in other Brazilian capitals. For more information, see Dreifuss 1987 and Ramírez 2007.

9 The IBF was founded in 1949 in São Paulo and was initially headed by the Brazilian jurist and philosopher Miguel Reale. The institution had in its cadres Luis Washington Vita, Vicente Ferreira da Silva, Renato Cirell Czerna, Heraldo Barbuy, Vilém Flusser, Leônidas Hegenberg, Roque Spencer Maciel de Barros, Ubiratan Borges de Macedo, Antonio Paim, and Ricardo Vélez Rodríguez. Between the 1960s and the 1980s, IBF operated with the Catholics of the Sociedade de Convivio, created in 1961 in São Paulo by Father Adolpho Crippa, from the Order of Salvatorians, with the active participation of Paulo Mercadante, Creusa Capalbo, Antonio Paim, Nelson Saldanha, Ricardo Vélez Rodríguez, and Ubiratan Borges de Macedo (Gonçalves 2017). 
was the case of the businessman Henry Maksoud, owner of companies in various fields, such as the contractor Hidroservice and the luxury hotel Maksoud Plaza.

Maksoud was one of the pioneers in the dissemination of Hayek's and Friedman's original ideas beyond the elite circles in Brazil, through the publication of the magazine Visão, book translations, and the TV show Henry Maksoud e você, trying to influence a group formed by what Hayek called "second-hand dealers of ideas" (Fonseca 1994). The Austrian economist came to Brazil three times between 1976 and 1981, at Henry Maksoud's invitation (Gross 2003). During his last visit, Hayek gave a lecture at the University of Brasilia attended by Eugenio Gudin, Roberto Campos, and Octávio Gouveia de Bulhões. Nonetheless, the activities promoted by Maksoud were never related to a specific organization and did not have specific aims. Neoliberal organizations only became formalized in the 1980s, during the country's re-democratization process.

In this period, conservative ideologists that had supported the military regime slowly lost their influence. During the transition to democracy, conservative discourses, characterized by aggressive anti-communist rhetoric, lost their appeal due to dwindling public and private support. The fight against communism was not a priority any longer. In fact, the idea of being a rightist was out of fashion at the time since it linked right wing people and organisations to the military regime. For similar reasons, political scientist Timothy Power (Power 2010) coined the epithet "the ashamed right" to characterize the Brazilian right after the end of the dictatorship.

The unfavourable scenario prompted conservatives, who were saddled with a frayed discourse and could not rely on great funding for their organizations, to defend free markets more organically and less pragmatically than in the 1950s and 1960s. In the words of Ricardo Vélez Rodríguez, a former member of the Sociedade de Convívio and former minister of education in Jair Bolsonaro's government:

In 1979, when I moved to Brazil for my doctoral studies, [Father Adolpho] Crippa offered me a research position in the Convívio publishing house. I accepted it, but I said: "Crippa, this is démodé. I think that communists must be fought against and criticized, but to dedicate oneself only to this is too little. We need to come up with a proposal. [...] He was a staunch anti-communist, but he wanted to change. Why? Because he received financial support from businesspeople from São Paulo, who no longer financed this anti-communist discourse, this discourse became worn out, and they no longer helped that much. I told Crippa: "Surely the business people are seeing that things are changing, that anticommunist discourse is not enough, that we need to think about Brazil from a more radical perspective and how to dismantle patrimonialism, so Brazil can really develop" (Interview with Ricardo Vélez Rodríguez, 2017). 
Vélez Rodríguez and other conservative intellectuals started to attend the circuits formed by the Instituto Liberal ${ }^{10}$ - founded in 1983 in Rio de Janeiro by the CanadianBrazilian businessman Donald Stewart Jr. and José Stelle, Hayek's translator and chief editor at Henry Maksoud's magazine Visão - and by the Instituto de Estudos Empresariais (IEE), created in 1984 by the businessmen Winston Ling and Willian Ling. The Liberal Institute had eight branch offices scattered across Brazil by the beginning of the 1990s, and in 1993 hosted the Mont Pèlerin Society's annual meeting in Rio de Janeiro. About the same time, other pro-market think tanks were created, such as the Instituto Atlântico, founded by old members of the Câmara de Estudos e Debates Econômicos e Sociais (CEDES) ${ }^{11}$ and headed by the economist Paulo Rabello de Castro, who had graduated from the Chicago School of Economics.

Most of the organizations founded at the time had an important interlocution with the Partido da Frente Liberal (PFL), now renamed Democratas (DEM), which housed politicians that used to be linked to the military regime's party, the Aliança Renovadora Nacional (ARENA). Roberto Bornhausen, whose brother, Jorge Bornhausen, was a politician affiliated to the PFL, presided the São Paulo chapter of the Instituto Liberal and the Instituto Atlântico, which was responsible for elaborating the party's political programme. Intellectuals linked to the former Sociedade de Convívio, such as Antonio Paim and Ricardo Vélez Rodríguez, also circulated in those think tanks and actively sought to influence it ideologically, ministering many formation courses to their members.

However, after sociologist Fernando Henrique Cardoso, affiliated to the Partido da Social Democracia Brasileira (PSDB), was elected to be President of Brazil in 1994 and after the end of hyperinflation, the institutes started to face increasing difficulties in keeping their sponsors. Many businesspeople believed it was no longer necessary to finance the dissemination of pro-market ideas since the federal government had already implemented these ideas in practice. According to Winston Ling:

10 "Liberal" in Brazil stands mainly for pro-market currents, being less associated to the defence of progressivist values than liberal groups in the Anglo-Saxon context.

11 CEDES was composed by a group of academics who, in its majority, were alumni of University of São Paulo, especially from the Fundação Instituto de Pesquisas Econômicas (FIPE). The group had great liberty to elaborate public policy proposals, despite the Chamber being sheltered in what Rabello de Castro referred to as "the national temple of conservatism", the Sociedade Rural Brasileira, an entity that was, in his view, profoundly anti-neoliberal. At the time, however, the Sociedade Rural was presided over by Renato Ticoulart Filho and other directors who, according to Castro, were more intellectual and open to innovations. The group also relied on bankers, such as then-president of Unibanco Roberto Bornhausen, and the Andrade Vieira family, owner of Bamerindus, a bank strongly linked to the state of Paraná's rural elites. According to the historian René-Armand Dreifuss, CEDES was maintained by fifty national and international companies and associations. Renato Ticoulart, in his own words, defined it as limited to "academic visions, of an absolute apoliticism", even if their aim was to "gather the business community in the sense of showing that neoliberalism is not equal to savage capitalism, to a misery producer order, but a leverage towards social development" (Dreifuss 1989: 52-53). 
After the Plano Real no Institute could levy any more funds because the sponsors would say: "We were already successful, we reached our goal, we are already in liberalism, we no longer need the Institute, inflation is zero, and now the thing is to work and make money, we don't need that anymore" (Winston Ling, April 2017).

Stewart Jr.'s death in 1999 accelerated the process, and, at the beginning of the 2000s, almost all branch offices of the liberal institutes had shut down. Amid the decline of the Instituto Liberal, the IEE focused on promoting the Fórum da Liberdade, that gathers right-wing leaders from different areas in the city of Porto Alegre, and the Instituto Atlântico, after approaching the PFL in the 1990s and supporting Roseana Sarney, the party's pre-candidate in the 2002 general elections, temporarily distanced itself from direct activity in national politics.

\section{The New Right: Mises and the Fight Against Globalism}

In 2003, amid the withering of Brazil's pro-market organizations, former union leader Luiz Inácio "Lula" da Silva's first presidential term started. Despite his leftist origins, the PT's leader adopted a more orthodox economic orientation than that of President Cardoso, with the objective of not upsetting the country's economic elites, especially those related to the financial markets. ${ }^{12}$ However, the outbreak of a corruption scandal known as mensalão in 2005 altered this perspective.

The scandal was named after the monthly instalments paid to deputies in exchange for their votes in favour of projects which were of interest to the Executive branch, and it became one of the most known corruption episodes in Brazil. ${ }^{13}$ It received wider media coverage than previous corruption scandals (Miguel and Coutinho 2007), and it involved high-rank government officials. In June 2005, Lula's chief of staff, José Dirceu, resigned from his office and, months later, had his parliamentary mandate revoked. In March 2006, Antonio Palocci, then Minister of Finance, also resigned from his post, despite having become the main actor for the maintenance of the orthodox economic policy of the government, and his successor, Guido Mantega, soon adopted a more heterodox approach.

In addition to the changes that occurred in government, the mensalão scandal also negatively affected the image of the PT, which had historically championed ethics in

12 This argument is developed in Lima 2016.

13 In an opinion research survey conducted in 2006 by Fundação Perseu Abramo, the PT's think tank, $76 \%$ of the population affirmed that the mensalão had occurred, which indicated low adherence to the party's official version of the scandal, according to which the financial transactions which were the original focus of the scandal were campaign money that was not accounted for by the PT's former treasurer, senator Delúbio Soares (Venturi 2006). 
politics, and contributed to an increase in distrust in the political system as a whole (Venturi 2006; Carreirão 2007; Paiva et al. 2007). Amid such a negative impact, the first movement linked to the New Right, the Movimento Endireita Brasil (MEB), was founded in 2006 in São Paulo by young lawyers led by Ricardo Salles (currently President Bolsonaro's Minister of Environment). ${ }^{14}$ The group intended to promote a campaign for Lula's impeachment. Nevertheless, the idea did not gain enough support due to the country's economic bonanza at the time, according to one of MEB's members, the historian Rodrigo Neves:

The MEB emerged in 2006 as a right-wing lawyers club. [...] It was formed by Ricardo Salles and some of his friends from São Francisco, PUC, Mackenzie [prominent Law Schools in São Paulo] who had recently graduated, who were against the PT and shocked by the mensalão scandal. [...] Their idea was: let us mobilize people to achieve Lula's impeachment. But, at the time, this did not gain support because it was 2006. Brazil was in the hype of an economic bubble that the PT created. Everybody saw an artificial increase in salaries, the economy grew in a frenetic bubble, so it did not gain support. Everybody knew that Lula had committed a crime and everybody knew Lula was corrupt and that the PT had bought votes, and nobody cared (Interview with Rodrigo Neves, April 2018).

Like the MEB members, most political pundits and opposition politicians affirmed that, after the mensalão, Lula would lose political and electoral support. However, the exunion leader got re-elected due to the economic improvement and the expressive electoral support of the lowest social strata (a phenomenon the political scientist André Singer (2012) called lulismo $)^{15}$. Still, he also finished his mandate with a popular approval rate of $80 \%$. Therefore, during his second term (2006-2010), there was a broad political consensus around the "Lulist" regulation, ${ }^{16}$ and disgruntled voices, both from the left and right, were rare. The existing right-wing parties (such as Bolsonaro's party at the time, the Partido Progressista, PP, ARENA's political heir), were part of the government's legislative alliance and other opposition leaders, from PFL/DEM or PSDB, did not seem to have great differences with the government's agenda.

14 "Endireita" means literally to straighten something, and figuratively a right turn in politics.

15 For Singer, lulismo constituted a particular phenomenon of Brazil's political history, a political programme that combined economic orthodoxy with the fight against inequalities through public policies focused on the poorest part of the population. Due to its difficulties in self-organizing, the poorest people of Brazil, which Singer calls the "sub-proletariat", would form the social basis of lulism, and would be represented, initially, by Lula and, afterwards, by the PT. The traditional middle class was opposed to this sub-proletariat, and after the mensalão scandal would become the social basis for anti-lulism, having as its main political expression, at the time, the PSDB.

16 The economist Leda Paulani defines the mode of regulation as "institutions, norms, calculus modes and procedures that ensure capital reproduction as a social relation" (Costa 2018). 
In civil society, dissonant voices also had little support. In 2007 there were some manifestations of the movement Cansei!, ${ }^{17}$ created after an airplane crash to protest against what its members viewed as an "aerial chaos" due to the bad management of airports by the PT government. However, the movement was ridiculed by the media and even by right-wing politicians such as the former governor of São Paulo Cláudio Lembo (PFL/DEM), who declared that the movement was composed of "silly rich ladies". Opposition to the government in the public sphere was limited to the activity of a few journalists in newspapers, magazines, and books criticizing Lula and the PT (Chaloub and Perlatto 2015), and people who decided to express their frustration and resentment in online forums.

At the time, the Internet became a refuge for anti-PT right-wingers or those who did not see their demands reflected in Lula's policies. Feeling cornered in mainstream publics, these individuals turned to the digital space to explore and sympathize with strangers through forum interactions, blogs, websites, and digital communities, encouraging the creation of discursive spaces that existed outside the dominant pro-government currents. Thus, in addition to the subaltern counterpublics that were active at the time, such as those formed by feminist activists (Medeiros 2017), LGBT+ and queer people, for example, there were also non-subaltern counterpublics formed by traditionalists, anti-globalists, supporters of the military regime, among others, who influenced the formation of the Brazilian New Right.

Whether or not counterpublics are subaltern, they all use counterpublicity: a radical counter-hegemonic political strategy based on intentional shock and disruptive performances. This occurs when members of specific audiences think that their ideas do not circulate in dominant audiences and the very manifestation of their worldviews and lifestyles are at risk. In light of this, and in light of the recent research on conviviality (Mecila 2017), it is also possible to say that counterpublics not only resignify identities and social positions by creating contradictions but also affect negotiation contexts, given their contradictory and ambivalent nature at the same time. As far as ambivalence is concerned, it is plausible to argue that counterpublics can democratize the dominant public sphere when they point out the lack of plurality in public debate and point out social suffering that is seldom or not at all considered by dominant publics.

At the same time, however, counterpublics also stimulate socio-cultural fragmentation and socio-political polarization. In particular, political polarization is fuelled by counterpublics since they operate according to the logic that there are only political enemies to be destroyed, and no legitimate political opponents who could be co-opted or defeated. For the members of counterpublics the impossibility of debate rests on the

17 In a loose translation, "Enough!", expressing the discontent of the group with the current political situation. 
perception that their enemies always act maliciously, that they are perverts, "fascists", have no humanity nor rationality, or have been submitted to "brainwashing" and indoctrination that lead them to defend evil ideas, which makes any rational debate impossible. Thus, even if members of counterpublics have rational-critical arguments to support their positions, they prefer to refuse the discussion. Moreover, they stigmatize other people who do not share their worldviews and seek to debate their ideas with political opponents.

The paradoxical character of counterpublics, on the other hand, lies in how they relate to conflict. Counterpublics not only establish the conflict between the dominant cultural horizon and an alternative horizon; they also make it possible to name the conflict and outline their views for the reorganization of public life. In general, dominant publics rationalize their cultural horizons and present them as consensual, or free from conflict, to perpetuate the dominance of their culture, codes, performances, ideas, and social structures. Counterpublicity denaturalizes these false consensuses. Its paradoxical dimension, though, lies in the difficulty of overcoming pure conflict and fabricating new, more inclusive, and reflective consensuses and forms of coexistence (Rocha and Medeiros 2020).

The emergence of the online social network Orkut was crucial in the emergence of right-wing counterpublics. In 2004, the network eventually became one of the main spaces for forming the new Brazilian right. The first step in this direction was taken in the 1990s by philosopher Olavo de Carvalho, who, by the early 2000 s, stopped writing for mainstream media outlets and focused only on his online activities. In 2002 he created a collaborative website called Mídia sem Máscara. In 2004 there were already two Orkut forums dedicated to the discussion of Carvalho's ideas. Two years later, he started broadcasting a podcast, and in 2009 , he began offering online philosophy lessons for a fee.

Significantly influenced by a marginal, esoteric, and anti-modern current of thought called traditionalism, also shared by Steve Bannon and Aleksandr Dugin (Teitelbaum 2020), Carvalho argued that the left had established a cultural hegemony in Brazil through the more or less conscious adoption of a political strategy developed by the Italian communist intellectual Antonio Gramsci. Such a process supposedly began during the re-democratization era in the mid-1980s. It involved the activity of mainstream media outlets, NGOs, publishers, universities, organizations that operated in the arts and humanities field, and international entities that defended progressive agendas like feminism, LGBT+ rights, and human rights in general. All those organizations were, according to Carvalho, part of an ongoing worldwide revolutionary process called "globalism". For globalists, only the intervention of a global authority, invested in an unprecedented power concentration, could solve the main contemporary issues, hence 
Caravalho's call for liberals and conservatives to unite in the fight against the leftist cultural hegemony and the upsurge of a "universal Leviathan" (Carvalho 2009).

Today, references to globalism and leftist cultural hegemony can be found in most discourses associated with contemporary right-wing leaders and groups, especially in the United States. In Brazil, these references were incorporated by readers of foreign authors and users of American internet forums, then readapted to the national context, and eventually shared with a larger audience through the translation of texts into Portuguese and dissemination in national digital forums. In this sense, Olavo de Carvalho's activity was fundamental for the emergence of the New Right in Brazil.

Around 2010, when Facebook became a popular social network in Brazil, Carvalho's ideas had been circulating on the internet for some years, and it was possible to find four communities that bore his name. According to Marcus Boeira, a Philosophy professor at the Universidade Federal do Rio Grande do Sul, who was also a reader of Carvalho's work and a user of these Orkut communities at the time:

Back then, it seems to me that there was a stronger Gramscian hegemony than there is today. Today, we have a greater pulverization, but not at the time. It was harder back then, we were no more than twenty persons working in these media, and the rest was practically ninety-nine percent of the people saying the same things. [...] He [Carvalho] said what we all wanted to say to journalists, university professors, people that worked in the media, people in the third sector, etc. He was saying everything that many people would like to say but had no voice. So, he, in a certain way, channelled all those voices (Interview with Marcus Boeira, June 2018).

Initially designed for the American public, Orkut rapidly became popular in Brazil. It is estimated that in January 2006, 75\% of all its users were from Brazil (Fragoso 2006), which indicated an early engagement of Brazilians in this type of social network in comparison to people of other countries. Between the years 2005 and 2007, the peak of Orkut's popularity in Brazil, internet access was limited largely to groups formed mainly by educated young people and adults, in its majority from middle and upper classes, and located primarily in the southern and south-eastern regions of the country (Comitê Gestor da Internet no Brasil 2007). Using Orkut, one could create communities about the most varied subjects, in which internet users could interact with each other through conversation topics. However, the use of fake profiles was quite common, and it contributed to the chaotic and sometimes violent development of debates (Fragoso 2006).

The environment provided by Orkut ended up fostering the constitution of right-wing counterpublics - debate arenas characterized by disruptive and indecorous language 
in detriment of rational-critical arguments, which are the basis of dominant publics' legitimacy (Warner 2002). Olavo de Carvalho used this kind of language consciously, to call attention through shock and indecorous behaviour and counteract the rationalcritical argumentation used by dominant publics through the defence of the use of swear words:

\section{THE USES OF SWEARING:}

I swear because it is NECESSARY.

It is necessary in the Brazilian context for demolishing polite language, which is a straitjacket that traps people, making them respect what does not deserve respect.

So, sometimes, when you disagree with someone but disagree respectfully, you are giving them more strength than if you agreed with them.

Because you are going against his idea, but you are reinforcing his authority.

Authority is respectability.

The problem of those people, those crooks I am talking about, is not their ideas. It is precisely the fact that they are scoundrels.

They are scoundrels, they are crooks, they are thieves.

G-O- F-U-C-K-Y-O-U-R-S-E-L-V-E-S! (Carvalho 2015).

Not only was the language disruptive, but the very ideas that circulated in such forums were also so conflictive to the dominant horizon that, if they were uttered without qualifications in dominant publics, they were very likely to cause hostile reactions. Among the most recurrent ones was Carvalho's idea that Brazil was dominated by a "Communist Gay dictatorship", that the Brazilian military dictatorship and its fight against so-called "terrorists" should be praised, and the idea expressed by young libertarians that "taxation is theft".

Although there were glaring differences and acute tensions between groups that met in those forums, they shared the fight against globalism and "left-wing cultural hegemony" in Brazil to a lesser or greater degree. Thus, although the defence of traditionalist and anti-modern ideas was restricted to a small group, the traditionalist counterpublic led by Olavo de Carvalho created a shared political language and constituted a broader discursive field (Alvarez 1990) that could unify different groups that had strong tensions among themselves. According to the then libertarian economist Joel Pinheiro da Fonseca: 
[Olavo de Carvalho] influenced many people. Many free-marketeers today have much more of a "right-wing bent" than a progressivist one, and he has played a significant role in that, I'm pretty sure of it. The thing about left hegemony, of forming this combative instrument, I think there is a lot there. Maybe he wasn't the only one, but I think he helped foster that. Without that kind of belief, perhaps we wouldn't have had that desire to fight and make things happen. Maybe, on a more practical level, he had a vital role in giving form to the vision that "we're in a lean, half-educated minority, without representation, we have to fight" (Interview with Joel Pinheiro da Fonseca, May 2017).

Libertarianism, which promotes free-market capitalism more radically than neoliberals linked to the Chicago School such as Ludwig von Mises and Murray Rothbard, was almost non-existent in Brazil until then. However, it was through Orkut that university students such as Filipe Celeti, and independent professionals like economist Rodrigo Constantino would be able to contact each other to share ideas, translate, and share texts:

In my last college year, I started to discover this new universe that, in a certain way, was all but non-existent in Brazil. The majority of texts were in English, so it was hard to have access to information. During that period [2005-2006] many free translation projects arose due to public interest. Many people created blogs to translate small texts and articles. So the need to disseminate those ideas was bubbling, and this agglutinated people: "Look, let's share these ideas, we need this". At Orkut, you typed the name of an author, and you had communities with twenty, thirty people, and most were not people from Brazil, [but] the Brazilians started to take over these spaces. So Orkut, with its communities, enabled people's meeting, the exchange of information, and promoted great debates on ideas (Interview with Filipe Celeti, April 2016).

I started working in the financial market and had a boss that was a known liberal in Brazil, Paulo Guedes [currently Brazil's Minister of Finances], who held a Ph.D. from Chicago. And he started giving me tips, "read this thing here, you will like it", and that thing was the Austrian School. So I discovered authors like Mises and Hayek very early on, and started, in parallel, working in the financial market, which is a propitious environment to fight against socialists, [...] to broaden my horizon of readings. Around my twenties, I was already, let's say, a libertarian. I always liked a good controversy too. [...] When I discovered Orkut and these communities where everybody spent the day debating, it was convenient, and we had endless debates there. Those were wonderful times. I loved the quarrelling and polemics. Orkut was a life-lesson, I loved debating, defending the ideas that I believed in, and I started to find an echo. I began to 
find people that were willing to discuss with me as well (Interview with Rodrigo Constantino, December 2016).

The right-wing counterpublics, however, did not limit themselves to the Internet. On June 2, 2006, the businessman Helio Beltrão Filho created the online community "Liberalismo Verdadeiro" for discussing economic liberalism on Orkut and gather people to establish a new organization inspired by the American Mises Institute. In 2007, one year after the digital community was founded, the Instituto Mises Brasil (IMB) was established through the reunion of prominent libertarian activists on the Internet, such as the brothers Cristiano and Fernando Chiocca. ${ }^{18}$

At the time of the creation of the IMB, another initiative started to take shape in the Orkut communities: the formation of Liber, a Brazilian political party inspired by the American Libertarian Party. ${ }^{19}$ In 2009, Liber already had an official website, a political programme, Twitter and Facebook accounts, and five hundred members that paid annual fees to the party. But the organizers failed to gather the 500,000 signatures necessary for the registration of a political party, and the initiative was scrapped.

Nevertheless, people who orbited around IMB, or actively participated, to a bigger or smaller degree, in Liber's institutionalization attempt, played an essential role in fostering a new libertarian militancy in Brazil, breaking with the high degree of elitism and centralization of the traditional right. Highly active on the internet, the militants started to promote their ideas on YouTube channels, forums, blogs, and social networks. This strategy, combined with the creation of study groups and participation in student movements and organizations throughout Brazil, ended up aggregating a growing number of like-minded people:

I got in touch with these guys from Fortaleza through Orkut. One of them had just entered the Federal University of Ceará School of Economics. His name was Raduan Melo. [The other was] Bruno Aguiar, and [the last one] Jeová, who attended Law School [...]. Then we [thought]: "We are all in Fortaleza, let's get together, become a group". Because we knew nothing - funny, right? I did not know where to find things. Then we set up a study group, the Sea Dragon group, in 2008, and our first reading was Mises' Human Action (Interview with Cibele Bastos, December 2015).

Orkut enabled people besides student representatives to express themselves. They could only express themselves freely in formal debates, meetings of

18 In 2015, a few years after the foundation of IMB, the Chiocca brothers left the institution and decided to found their own organization, the Rothbard Institute.

19 Founded in 1971 by David Nolan in the state of Colorado, United States, the Libertarian Party promotes libertarian ideas. 
student committees, and elections. At the time, there were Olavo de Carvalho's communities, Liberal communities [...]. On Orkut, I did not discuss politics a lot because I found it boring. I am a bit old-fashioned. I prefer to talk to people face to face in the hallways. I participated in an election [at the Federal University of Maranhão] for the Student's Central Directory, and I succeeded, I was elected in 2010 (Interview with Lourival de Souza, April 2017).

I met some friends who told me about Olavo de Carvalho and Rodrigo Constantino. I began reading some of their texts, and we discussed them between ourselves, not only the texts they recommended but also some that we chose on our own. I think I started to get in touch with this around 2009 and 2010, which coincided with when I began to have a political activity at college. [...] Many debates started after we began to use Facebook; before that, we were on Orkut. You can see that some people disagree with some types of thinking, ideologies or political practices. [But they are] completely alienated from decision-making processes. [We ran for the students' committee elections] and we had many supporters (Interview with Fernando Fernandes, March 2017).

Simultaneously, militants also circulated in older forums and organizations, such as the Fórum da Liberdade, promoted annually by the IEE. Here it is possible to highlight the roles of Bernardo Santoro, Rodrigo Constantino, and Fábio Ostermann. While Ostermann had a fundamental role in structuring new key organizations dedicated to pro-market militancy, such as the Instituto Ordem Livre and Estudantes pela Liberdade, Santoro and Constantino were responsible for the restructuring of the former Instituto Liberal in Rio de Janeiro:

In 2012, I worked as the Institutional Relations Director at the Instituto Liberal [IL] in Rio de Janeiro. The organization was dying, and I knew people all over Brazil who shared a pro-market viewpoint. I knew everybody from the IEE, from the Instituto Para a Formação de Lideranças, from the Fundação Friedrich Naumann [FFN], from the attempts of forming liberal parties such as the Partido Novo, ${ }^{20}$ the Partido Federalista, and Liber. I was Liber's president at the time. My first event as president was a workshop at FFN on raising money and so on, and I went as an IL representative and presented a project for restructuring the IL. Everybody thought it was terrific, but no one spared me a dime. Later, I explained that project to local businesspeople in Rio de Janeiro, including Rodrigo Constantino, and he liked it. Afterward, in another pro-market event in Rio Grande do Sul [the Fórum da Liberdade], Constantino talked to some more

20 The Partido Novo, founded in February 2011 under the leadership of former executive of the financial market João Amoêdo, obtained its official status in November 2015. The party promotes a free market agenda based on greater personal liberty and opposes State intervention in the economy (Novo n.d.). 
people, turned to me, and said: "Bernardo, the project is approved, we have funding". I left my job, went to the Institute, and invited Fábio Ostermann, who was a great friend of mine and also knew everybody, to be the new Institutional Relations Director (Interview with Bernardo Santoro, October 2015).

The contact between different generations provided access to already established promarket contact networks inside and outside the country and new sources of funding. The example of the Instituto Ordem Livre illustrates this. Created officially in 2009, it fostered Liberdade na Estrada, sponsored by car rental giant Localiza, Salim Mattar's company, a businessman who supported the diffusion of pro-market ideas since the 1980s. Liberdade na Estrada promoted libertarian lectures in universities throughout Brazil. Its five first editions reached fifty universities in more than thirty cities (Instituto Ordem Livre n.d.).

Eventually, the militancy in higher education became more articulated and institutionalized with the creation of Estudantes Pela Liberdade (EPL). Inspired by its American namesake, it favoured efforts for coordinating students who wanted to organize study groups and run for students' committee elections in different states. ${ }^{21}$ Since its establishment, the EPL has organized 650 events across public and private universities, supported the founding of more than two hundred study groups, and, in 2014, had six hundred voluntary leaderships that helped to forge new community bonds (Polletta and Jasper 2001):

When I attended EPL's national conference in 2013 in Belo Horizonte, the sense of family within the movement became very clear to me. Because of a group of crazy people who started doing this on Orkut, you get a ride in a crowded car, and people treat you well, there's a lot of chatting: "How do you do it in your state?", and so on. Suddenly, I had this sense of belonging, and it was great (Interview with Gabriel Menegale, January 2017).

Pro-market and libertarian ideas dominated the then-emerging New Right. According to Rodrigo Neves from Endireita Brasil, conservatives had less success mobilizing civil society than attracting young free-market defenders. This continued the trend where conservatives circulated in think tanks and pro-market organizations:

I arrived at the Fórum da Liberdade with the reputation of being a conservative, a person from the Endireita Brasil movement, a person that had started a conservative movement at the University of São Paulo. People came to talk to me about conservatism. So, on the first day of the Fórum I was already Mr. Conservative. The warm-up to the Forum was at the First Conference on the Austrian School. I received the invitation for free from Helio Beltrão, because of 
our [operation on the] Dia Livre de Impostos. [There were] anarcho-capitalists, libertarians, me, a staunch conservative, and Marcel Van Hattem, who was also a conservative. Marcel says he is a free-marketeer, but he always had some conservative ideas, because he is very religious with a strong conservative bias. [Question: At the time, who else would you call a conservative that attended these spaces?] Me and Ricardo Salles. Both of us were swimming against the tide, because this new right-wing movement was formed mainly by libertarians and free-market defenders. Ricardo used to call himself a right-wing freemarket defender, or he could not sell his product. But I declared myself: I am a conservative. I was one of the people who started to change this setting. Marcel, he used to hold back because he was more focused on bringing the debate to free-market economics, even if he had some conservative values. Ricardo did the same (Interview with Rodrigo Neves, April 2018).

However, by the end of Lula's second term, the "pro-market and libertarian hegemony" of the new right gave way to the conservatives. In the 1960 s, conservative organizations such as TFP had an important impact on civil society, mobilizing the anti-communist discourse and supporting the civil-military coup of 1964 (Motta 2002). But after redemocratization and the decline of communism in the 1980s, both older leaders and organizations linked to the Catholic Church, and more recent ones related to evangelical churches, started to focus on issues concerning the emerging feminist and LGBT+ agenda.

There was a very slow progress under both the $\mathrm{FHC}$ and Lula administrations, especially regarding abortion laws. ${ }^{22}$ In this sense, it is important to emphasize that Lula, a former union leader, was elected with conservative voters' support. At the time, there was still a dissociation between defending a conservative agenda and voting on left-wing candidates for the presidency (Nishimura 2004). However, during Lula's second term, bills like the Maria da Penha Domestic Abuse Law, proposed in 2004 and adopted in 2006 (Senado Federal 2006a), and the criminalization of homophobia, proposed in 2006 (Senado Federal 2006b) marked a big change.

\section{Breaking with the System: Bolsonaro's Rise to Power}

After thirty years as a legislator, former army captain Jair Bolsonaro appeared on the political scene as a palatable leader for the emergent New Right in 2014, when he received a record 464,000 votes in Rio de Janeiro's legislative elections, four times

22 The Draft Bill 1131/1991, elaborated by the then PT federal representatives Eduardo Jorge and Sandra Starling, which proposed decriminalizing abortion, was tabled in 1999 during FHC's second term. In 2003, 2007 and 2011, during the PT administrations, it was once again tabled (Câmara dos Deputados 1991). 
the amount he obtained in the previous election. In the same year, one of his sons, Eduardo Bolsonaro, was elected as a Rio de Janeiro federal representative for the first time, with 82,000 votes. The vast difference in the number of votes comes from two main factors: the early engagement in social networking ${ }^{23}$ and an emphasis on consistently defending conservative values, especially from 2011 onwards. ${ }^{24}$

Bolsonaro historically has always sought to meet the demands for better wages from the low-rank military, his electoral base, and position himself frontally against human rights, not afraid of asserting himself as an anti-communist, right-wing politician. In the 1990s, he asserted that Congress should be closed down and that President Fernando Henrique Cardoso should be shot dead. However, in 2002, when he lobbied to nominate the communist Aldo Rabello to the Ministry of Defence, he claimed that he had voted for Lula. In an interview, he ironically stated that communists nowadays drink whisky and live well (Folha de São Paulo 2002). At the time, Bolsonaro's party was part of the PT's coalition, and political pragmatism spoke louder than ideologies.

But things changed in Lula's successor Dilma Rousseff's first mandate. In only four years, Brazilian society went through a "progressivist shock". In 2011, the Comissão Nacional da Verdade was created to investigate the State's crimes during the military dictatorship. The same year, the Superior Tribunal Federal (STF) recognized the right to same-sex marriage. The following year, the STF also recognized the right to abortion in foetal anencephaly cases and confirmed the validity of the racial quota system in public universities. A project for a constitutional amendment to widen labour rights to domestic workers, known as PEC das Domésticas, and a law prohibiting physical punishments and cruel and degrading treatment to children and adolescents, known as Lei da Palmada were promulgated in 2013 and 2014, respectively. Simultaneously, Brazilian versions of the Canadian Slut Walks popped up throughout the country between 2011 and 2012, popularizing feminism among young women and fostering new feminist activism on the streets and social networks (Medeiros and Fanti, 2019).

23 Jair Bolsonaro created a Twitter account in 2010 and a Facebook fan page in 2013.

24 As pointed out by research conducted by BBC Brazil based on more than 1,500 speeches given by the then representative at the Deputies' Chamber plenary during 27 years: "[...] Bolsonaro from the start of his career was more concerned with the defence of military interests [his electoral basis] than arguing with the PT and the left. [...] In his first mandate as a representative, from 1991 to 1994, words such as 'military', 'armed forces', 'benefits', 'salary' and 'pensions' appeared 702 times in the abstracts and key-words of the 279 speeches he gave in the Chamber's Plenary. During his current mandate, from 2015 until now, the same set of sixteen words have appeared only 110 times, in a total of 143 speeches. Over time and with the increase in his national projection, the corporative issues of the Army, the Navy and the Air Force receded. Bolsonaro's time in the tribune started to be occupied with issues that 'appealed' to the deputy's new public, who knew him mainly from the internet, and a new set of 16 terms, such as 'human rights', 'PT', 'torture', 'Cuba', 'left', and 'gays' had a peak in his last mandate (2011 to 2014), appearing 297 times in this period, while they were only cited 41 times in Bolsonaro's first mandate (1991-1994)" (Shalders 2017). 
Facing such a scenario, Bolsonaro did not hesitate to lead the reaction to the so-called progressivist shock. Flanked by other conservative legislators, he managed to bar the printing of leaflets of the programme Escola sem Homofobia, formulated as early as 2004 and derogatorily called Gay Kit (Soares 2015). However, he was unsuccessful in his attempt to bar the installation of the Comissão Nacional da Verdade and the approval of same-sex marriage bill. And there was still the possibility that Dilma Rousseff, if reelected, would dedicate herself to the legalization of abortion, once she had claimed in 2007 that such practice should be decriminalized (Pires 2010).

Due to Bolsonaro's activity during this period, which was extensively publicized in his social media accounts, many conservatives, previously more dispersed in forums and free-market organizations, started to flirt with the former army captain. At the same time, Orkut libertarians, such as Bernardo Santoro and Rodrigo Constantino began labelling themselves liberal-conservatives, pointing to a historical tendency of free-market defenders who adhered ideologically or pragmatically to conservatism (Constantino 2018). ${ }^{25}$ Such positioning caused discomfort among the militancy for some time, as the label liberal-conservative seemed like an oxymoron, ${ }^{26}$ and, eventually, caused tensions in various groups, ${ }^{27}$ especially in and around matters such as abortion rights. According to lawyer José Carlos Sepúlveda, member of the Plínio Corrêa de Oliveira Institute, the organization that succeeded the old TFP:

25 As with the support of American libertarians for the conservative Senator Barry Goldwater in the 1960s (Doherty 2007), and the support of F. Hayek for the British conservative leader Margaret Thatcher (Cockett 1995): in each of these cases, support was mixed with important ideological and identity tensions.

26 "Some people think that the expression liberal-conservative is an oxymoron. The confusion starts at the beginning of everything, when Burke himself, the great conservative, became a member of the Whig Party, which was a Liberal party that opposed the Tories. So what was he: liberal or conservative? I think these words have different meanings according to place and time, and ideological interests. Those who say that the label liberal-conservative is semantically impossible say this out of ideological interests. They are, above all, Libertarians, which want to distance themselves from values such as order or traditions, so I will not grant them the right to define liberalism. I believe that the liberal-conservative thought exists and it is not only used in Brazil, but also abroad. [...] I believe that the boundaries of these terms are ill-defined. The polemic on its use is open, but I do not see anybody in authority to solve it. To settle the polemic, I would say the following: 'I am an old Burkean Whig, with national colours"' (Interview with Lucas Berlanza, March 2017).

27 "The (Liberty) Express was created in 2012, but it was not well delineated as to being either liberal or conservative. Instead, it orbited a common place of these two philosophies, which is the Natural Law triad of life, freedom and property. Liberals and conservatives shared those views. Over time, all the remaining liberals left. Because those who called themselves liberals were, in fact, I would say, pseudo-liberals, because everyone called themselves liberals [but] were liberals of conservative hues, they had emerged under the sign of some conservative group. So I saw the liberal world under the blessings of Nelson Rodrigues, someone else under the blessings of Ortega y Gasset, who is a conservative and aristocratic liberal, another by a monarchist author, culturally very conservative. So, at the end of the day, other issues of society were discussed and it ended up taking a conservative form" (Interview with Lourival de Souza, April 2017). 
The leaders of pro-market movements defended liberal ideals. Still, many people - and I noticed a lot of this in north-eastern Brazil - who found shelter there were not exactly liberal. I see this as a border, a wide border of the conservativeliberal movement. [...] The pro-market movement ended up gathering many conservative people. Some ended up breaking with the movement. Others stayed, but with ideas that tended more towards conservatism. [...] One thing that Plinio [Corrêa de Oliveira] always defended in his books is that if we take an ordinary, uneducated woman, she has her inner world. If we speak to her, she probably holds conservative ideas. Still, she is unfamiliar with both the conservative and liberal movements, or anything at all, but her mentality is conservative. Also, PT's Fundação Perseu Abramo recently published research showing that even people from the outskirts of big cities are conservative. Well, they are figuring out what was obvious, right? And it seems to be the following: contrary to other countries, things here are more fluid. Sometimes I see that people want to put a straitjacket on the talk about Brazilian reality, as if we were in America, for example (Interview with José Carlos Sepúlveda, April 2017).

In 2014 Bolsonaro had established himself as one of the leaders of the conservative reaction that had taken over the country. In the following years, his political projection reached new heights, peaking during the protests for the impeachment of Dilma Rousseff. During the presidential elections of 2014, the militants of the emerging New Right pragmatically campaigned for PSDB candidate Aécio Neves, and they all supported him in the runoff. At the time, Rousseff's defeat was taken for granted by the opposition due to the report of a corruption scandal related to the most prominent state company in the country, oil giant Petrobrás (Singer 2018). Thus, the shattering of expectations with the announcement of her reelection was such that soon it was suggested that the election was rigged. Opponents of the PT began to express outrage, which provided a welcoming environment for anyone who wanted to protest against the situation.

The first pro-impeachment protest was called only six months after the reelection of Dilma Rousseff. The call for the protest was made on the Facebook page of Paulo Batista, a state legislator candidate from São Paulo also known as Raio Privatizador. His campaign was coordinated by libertarian militants and members of the Movimento Brasil Livre (MBL), the main pro-market movement in the country. ${ }^{28}$ In humorous videos shared on YouTube, Batista was shown firing "privatizing rays" on supposedly communist cities. Although Batista was not elected, around 2,500 people attended the

28 Founded initially by a group of friends led by Fábio Ostermann as a Facebook page to coordinate the pro-market militancy during June 2013 , MBL was recreated by the activist Renan Santos on November 15, 2014. Since then, it has served as the main pro-market movement in the country, and one of the groups that led Dilma Rousseff's pro-impeachment campaign. 
protest, which was supported by Olavo de Carvalho. For the first time, it gathered all the representatives of New Right groups in the streets of São Paulo, including legislator Eduardo Bolsonaro. The protests continued being called by different movements, until March 15, 2015, when, according to Datafolha Institute polls, more than 250,000 people, bearing the national flag's colours, filled the streets of São Paulo to demand Rousseff's impeachment, encouraging the organizers to call new protests later in the year.

According to opinion research conducted by Esther Solano, Márcio Moretto Ribeiro, and Pablo Ortellado during the protests in São Paulo in August 2015, 96\% of the protesters were dissatisfied with the political system. $73 \%$ said they did not trust political parties, and $70 \%$ claimed that they did not trust politicians (Rossi 2015 ). Thus, beyond sharing the rejection of the PT and its leaders (Telles 2016), rejection of the political system as a whole was widespread among protesters, probably due to the generalized perception that the political system was corrupt.

After the 2005 mensalão scandal, which affected the PT's leadership, only $5 \%$ of the population considered corruption the country's main problem. However, in October 2015, these numbers had increased to $34 \%$ (Singer 2018). This increase resulted from a series of protests against corruption that took place between 2011 and 2012, after the mensalão scandal trial, and especially after the massive street protests of June 2013. The 2013 uprisings, started by the Movimento Passe Livre (MPL), demanded reduced public transportation fares and were violently repressed by the police. They gathered millions of people throughout Brazil in dozens of protests that, despite their several demands, turned against the political system as a whole, perceived as impermeable to the population's appeals (Nobre 2013).

The outrage against the political system increased the following year due to the beginning of a huge anti-corruption operation, responsible for the imprisonment and condemnation of several politicians and businesspeople. Initiated in March 2014 with a money laundering report at Petrobrás, and inspired by the Italian Mani Puliti, the Operação Lava Jato soon gained wide mainstream media coverage and rapidly made one of its architects, judge Sérgio Moro, the most prominent symbol of the fight against corruption in the country.

Thus, amid a crisis in public trust aggravated by the worsening economic situation, it is understandable that $56 \%$ of the protesters agreed with the statement "someone outside of the political system would solve the crisis". For $64 \%$ of the interviewees, this person could be an "honest judge", and for $88 \%$ an "honest politician". When asked who inspired more trust, $19.4 \%$ affirmed that they strongly trusted Jair Bolsonaro, who headed the list. Only $11 \%$ said they trusted PSDB, the party most of them had voted for 
in 2014, and only $1 \%$ said they trusted the Movimento Democrático Brasileiro (MDB), the party of the then Vice-President Michel Temer, who would occupy the presidency if the impeachment demanded by protesters was successful.

Bolsonaro was one of the few politicians who could participate in the anti-impeachment demonstrations and be applauded by the crowds, unlike other opposition leaders. Thus, at the end of 2015, the former military captain, considered by part of the population as one of the few honest politicians in the country, became a natural presidential candidate by defending law and order, advocating anti-system rhetoric, and attacking the PT and the left in general. His military background and consistent support for the death penalty, the reduction of the age of criminal responsibility for minors, and the injunction of forced labour among prisoners were seen as some positive attributes among his supporters. He was regarded as the only one capable of reducing violence through repressive measures and disciplining society in the face of moral degradation in a country where the rights of leftists, gays, and Black people were supposedly better protected than those of the "ordinary citizen".

The former army captain, who married an evangelical woman in a ceremony presided by the conservative televangelist pastor Silas Malafaia in 2013, gained prominence for opposing "gender ideology" and supporting discipline in schools. His appeal to the conservative Christian public would increase when, in March 2016, Bolsonaro formally joined the Partido Social Cristão (PSC), which gathered a significant part of the conservative Christian leaders in Brazil, and was baptized in the Jordan river by Pastor Everaldo, the party's candidate in the 2014 presidential elections.

However, Everaldo's presidential campaign became less known by its exaltation of Christian values than by the exhaustive repetition of the motto "let's privatize everything". The motto was a brain-child of Bernardo Santoro, director of the Instituto Liberal at the time, who was Liber's ex-president and an active participant in Orkut counterpublics in the mid-2000s. Santoro joined PSC in 2014 and became a selfstyled "liberal-conservative". He focused on actively influencing Jair Bolsonaro and his sons to embrace free-market radicalism. In his own words, Santoro intended to diffuse free-market radicalism to broader sections of the population, such as members of the impoverished middle class and "Uberized" labourers. ${ }^{29}$

29 According to sociologist Ludmila Costhek Abílio, "uberization consolidates the passage from a worker statute to one of nanobusinessperson, permanently available for work, removing minimum working guarantees while maintaining workplace hierarchies; yet, it appropriates, administratively and productively, a loss of publicly established working forms. However, this appropriation and subordination may operate on new logic. We can understand uberization as a possible future for companies in general, which become responsible for providing infrastructure for their 'partners' to execute the work; it is not difficult to imagine hospitals, universities, and companies in a wide range of fields adopting this model and using the work of their 'just-in-time collaborators' according to their needs" (Abílio 2017). 
Santoro's mission was a tough one. At the time, free-market defenders saw Bolsonaro as an adept of national developmentalism, a set of State-centred economic policies advocated by the military dictatorship in the 1970s. Santoro did not give up, and his efforts soon started to pay off. In March of that year, Jair's son Eduardo Bolsonaro enrolled in a course on Austrian economics offered by the Instituto Mises Brasil, established by Hélio Beltrão Jr, the creator of the Orkut community "True Liberalism". His brother, who served as a municipal councillor in Rio de Janeiro, decided to run for mayor in the elections of that year with a message strictly aligned with the agenda of Santoro.

Bolsonaro seemed less inclined to market radicalism than his sons, although he decided to participate in events promoted by the market circuit as a presidential pre-candidate. In 2017, he was introduced to Paulo Guedes by Winston Ling, founder of the IEE. Guedes, a Chicago School graduate and a well-known figure of the financial market circuits, founded the Instituto Millennium in 2006, a pro-market think tank based in Rio de Janeiro, with Rodrigo Constantino and Hélio Beltrão Jr.

But the pro-market milieu was initially suspicious of Bolsonaro and tensions grew among his new party's political leaders, whose extreme political pragmatism often sacrificed the right-wing public agenda. The last straw was PSC's alliance with the Partido Comunista do Brasil ( $P C$ do B) in the 2016 gubernatorial elections in Maranhão, forcing Bolsonaro and his sons, staunch anti-communists, to search for a new party. ${ }^{30}$ In August 2017, the Bolsonaros announced their affiliation with the Partido Ecológico Nacional (PEN). To house the former captain's presidential aspirations, the party changed its name to Partido Patriota. As General Secretary of the party, Bernardo Santoro introduced Bolsonaro to a young economist called Adolfo Sachsida, a University of Brasilia Ph.D. and analyst at the federal government's Instituto de Pesquisas Econômicas Aplicadas (IPEA). Sachsida, at Santoro's request, formed a group of eleven economists that met weekly with Bolsonaro.

The opposition of free-market defenders to Bolsonaro seemed to decline gradually. In December 2017, Rodrigo Constantino publicly suggested that Paulo Guedes should be the Minister of Economy in a future Bolsonaro government. However, in early 2018, the pre-candidate decided to leave the Partido Patriota and affiliate to the Partido Social Liberal (PSL). The sudden change in affiliation to a new party quickly caused discomfort among the libertarian militants of PSL that had gathered since 2016 at the group LIVRES. Staunch antibolsonaristas, LIVRES militants left the party shortly after Bolsonaro joined it, adhering to the Partido Novo.

30 When Bolsonaro left the PSC, Paulo Rabello Castro, founder of the Atlantic Institute in 1992, became the party's candidate in the 2018 election. However, in the same year, he withdrew his candidacy and started to figure as candidate for vice-president on presidential candidate Álvaro Dias's Podemo's ticket. 
The pre-candidate eventually caused another shock when he shunned participation in the presidential debate organized by the Fórum da Liberdade, which gathered rightwing leaders and ideologues yearly. In order to end once and for all lingering suspicions due to his erratic political movements, Bolsonaro decided to seal his alliance with the pro-market defenders by announcing in the first semester of 2018 that Paulo Guedes would be his Minister of Economy. Despite all sorts of suspicions, tensions, and resentments, most market fundamentalists actively supported Bolsonaro's presidential campaign, bringing together the New Brazilian Right around a libertarian-conservative amalgam.

After the first round of the elections ended in October 2018, Bolsonaro had collected more than half of the valid votes in 12 states and the Distrito Federal, which surprised many political analysts. Bolsonaro was disappointed by the results, as he felt he could win the elections in the first round. On the other hand, the counterpublic militants were impressed by the votes he had received and leaders of the pro-impeachment protests, such as law professor Janaína Paschoal, journalist Joice Hasselmann, and then federal legislator Eduardo Bolsonaro, all PSL candidates, received more than 1 million votes each. The party became the second-largest parliamentary bench in Congress, with 52 members, increasing six times in size its presence in the federal lower legislative house.

\section{Conclusion}

Bolsonaro's victory, as well as that of many New Right activists, was a result of a long political and social process that can be traced back to the mensalão corruption scandal in 2005 and culminated with a firm electoral rejection of the PT and Lula's arrest in 2018. Even though many factors explain Bolsonaro's victory - economic and social crisis, rampant violence and crime, Lula's imprisonment, and the disappointment with the PT and the political system as a whole, including the intense political content sharing through social networks (Brito Cruz 2019) ) $^{31}$ it is of paramount importance to consider the formation of emerging New Right militancy networks which diffused new ideas during a series of critical moments between 2011 and 2016: the progressivist shock (2011-2014), the protests against corruption (2011-2012), the mensalão scandal trial (2012), the uprisings of June 2013, the Operação Lava Jato (2014), Dilma Rousseff's reelection (2014), and pro-impeachment protests (2014-2016).

Bolsonaro came to symbolize the burgeoning outrage against the PT and the political system, and the desire for law, order and discipline in Brazilian society. His closeness

31 Leticia Cesarino (2019) proposes an interesting discussion about digital populism based on Bolsonaro's use of WhatsApp in his campaign. 
to evangelical leaders, Olavo de Carvalho's followers, and radical pro-marketeers delivered him a wide-ranging mixture of personnel ready to serve in government, apart from those recruited into the army that also exalted the military dictatorship. The disruptive and indecorous language characteristic of counterpublic discourse became frequent in official communications, as in Donald Trump's administration (Thimsen 2017), contrary to Michael Warner's hypothesis that the counterpublics would normalize if their members became part of dominant publics.

However, there are significant tensions between the new right-wing groups. In this sense, the first two years of Bolsonaro's government were a game-changer for the New Right, which subsequently has begun to show signs of division between unconditional Bolsonaro supporters that still employ disruptive and indecorous language in social networks, critical supporters, and a few opponents, who consider him a threat to Brazilian democracy.

While the emergence of counterpublics facilitated by digital media (Downey and Fenton 2003) points to increased representation of certain groups in the public sphere, to the extent that it allows more people to participate and influence the public debate, it can also have harmful effects. The increased fragmentation of the public (Sunstein 2017) and the formation of the so-called "bubble effect", a process of feedback of ideas and information by internet users through filters and algorithms (Pariser 2011), may lead to the intensification of political radicalization (Downey and Fenton 2003), and counterpublicity may facilitate the popularization of authoritarian ideas incompatible with the democratic regime.

\section{Bibliography}

Abílio, Ludmila C. (2017): "Uberização do trabalho: subsunção real da viração", in: Passa Palavra, February 2, at: https://passapalavra.info/2017/02/110685/ (Last access 21.09.2020).

Alvarez, Sonia (1990): Engendering Democracy in Brazil: Women's Movements in Transition Politics, Princeton: Princeton University Press.

Aranha, Francisco Arantes (2016): Tecnocracia e capitalismo no Brasil num estudo de caso: a Associação Nacional De Programação Econômica e Social (Anpes) (1964-1967) (Masters' dissertation), Goiânia: Universidade Federal De Goiás.

Boas, Taylor and Gans-Morse, Jordan (2009): "Neoliberalism: From New Liberal Philosophy To Anti-Liberal Slogan", in: Studies in Comparative International Development, 44, 2, 137-161. 
Boianovsky, Mauro (2018): "The Brazilian Connection in Milton Friedman's 1967 Presidential Address and 1976 Nobel Lecture”, Chope Working Paper No. 11, Durham, NC: Center For The History Of Political Economy Duke University.

Brito Cruz, Francisco (2019): Definindo as regras do jogo: as regulações da campanha política e a internet (Doctoral thesis), São Paulo: Faculdade de Direito da Universidade de São Paulo.

Câmara dos Deputados (1991): Online at: https://tinyurl.com/3zpz6arf (Last access 11.09.2020).

Carreirão, Yan (2007): "Identificação ideológica, partidos e voto na eleição presidencial de 2006", in: Opinião Pública, 13, 2, 307-339.

Carvalho, Olavo de (2009): "A revolução globalista", at: https://tinyurl.com/3rxqqp95 (Last access 23.09.2020).

(2015) "O uso do palavrão", August 25, at: https://www.facebook.com/carvalho. olavo/posts/535327239952688/ (Last access 02.02.2021).

Casimiro, Flávio Henrique (2011): "A dimensão simbólica do neoliberalismo no Brasil: o Instituto Liberal e a cidadania como liberdade de consumo", in: Cadernos de Pesquisa do Cdhis, 23, 1, 227-250.

Celikates, Robin (2015): "Digital Publics, Digital Contestation: A New Structural Transformation of the Public Sphere?", in Celikates, Robin; Kreide, Regina and Weshe, Tilo (eds.), Transformations Of Democracy: Crisis, Protest And Legitimation, London: Rowman \& Littlefield, 159-174.

Cesarino, Letícia (2019): "On Digital Populism in Brazil", in: PoLAR: Political and Legal Anthropology Review, April 15, at:

https://polarjournal.org/2019/04/15/on-jair-bolsonaros-digital-populism/ (Last access 23.09.2020).

Chaloub, Jorge and Perlatto, Fernando (2015): "Intelectuais da 'Nova Direita' brasileira: ideias, retórica e prática política", in: Anais dos Encontros da Associação Nacional de Pós-Graduação e Pesquisa em Ciências Sociais, $39^{\circ}$ Encontro, Caxambu, October 26-30, São Paulo: Anpocs.

Cockett, Richard (1995): Thinking the Unthinkable: Think Tanks and the Economic Counter-Revolution 1931-1983, London: HarperCollins. 
Comitê Gestor da Internet no Brasil (2007): Indicadores de uso da internet no Brasil, 2005/2006, at: https://www.cetic.br/media/docs/publicacoes/10/pal2007ofid-11. pdf (Last access 23.09.2020).

Constantino, Rodrigo (2018): Confissões de um ex-libertário: salvando o liberalismo dos liberais modernos, São Paulo: Record.

Costa, Henrique (2018): Entre o lulismo e o ceticismo, São Paulo: Alameda.

Dardot, Pierre and Laval, Christian (2016): A nova razão do mundo: ensaio sobre a sociedade neoliberal, São Paulo: Boitempo.

Desai, Radhika (1994): "Second-Hand Dealers in Ideas: Think-Tanks and Thatcherite Hegemony", in: New Left Review, 203, 147-155.

Doherty, Bryan (2009): Radicals for Capitalism: A Freewheeling History of the Modern American Libertarian Movement, New York: PublicAffairs.

Downey, John and Fenton, Natalie (2003): "New Media, Counter-Publicity and the Public Sphere", in: New Media \& Society, 5, 2, 185-202.

Dreifuss, René Armand (1987): 1964 - A conquista do Estado: ação política, poder e golpe de classe, Rio De Janeiro: Vozes.

(1989): O jogo da direita na Nova República, Rio De Janeiro: Vozes.

Fonseca, Francisco (1994): A imprensa liberal na transição democrática (1984-1987): Projeto político e estratégias de convencimento (Revista Visão e Jornal 0 Estado De São Paulo) (Masters dissertation), Campinas: Universidade Estadual De Campinas.

Gonçalves, Rodrigo Jurucê Mattos (2017): História fetichista: o aparelho de hegemonia filosófico Instituto Brasileiro De Filosofia Convivium (1964-1985), Anápolis: Editora da Universidade Estadual de Goiás.

Gros, Denise (2003): Institutos liberais e neoliberalismo no Brasil da Nova República (Doctoral thesis), Porto Alegre: Fundação de Economia e Estatística Siegfried Emanuel Heuser.

Hauck, Juliana (2015): Think Tanks: quem são, como atuam e qual seu panorama de ação no Brasil (Masters dissertation), Belo Horizonte: Universidade Federal de Minas Gerais.

Instituto Ordem Livre (n.d.): "Liberdade na estrada", at: http://ordemlivre.org/lne (Last access 23.09.2020). 
Jackson, Ben (2010): "At the Origins of Neo-Liberalism: The Free Economy and The Strong State, 1930-1947", in: The Historical Journal, 53, 1, 129-151.

Lima, Flávia (2016): "PT e PSDB já foram ortodoxos e heterodoxos, aponta estudo", in: Valor Econômico, Rio de Janeiro, April 8, at: https://valor.globo.com/brasil/ noticia/2016/04/08/pt-e-psdb-ja-foram-ortodoxos-e-heterodoxos-apontaestudo.ghtml (Last access 11.09.2020).

Mecila (2017): "Conviviality in Unequal Societies: Perspectives from Latin America. Thematic Scope and Research Programme", Mecila Working Paper No. 1, São Paulo: Maria Sibylla Merian International Centre for Advanced Studies in the Humanities and Social Sciences Conviviality-Inequality in Latin America.

Miguel, Luis Felipe and Coutinho, Aline (2007): "A crise e suas fronteiras: oito meses de 'mensalão' nos editoriais dos jornais”, in: Opinião Pública, 13, 1, 97-123.

Mises Institute (n.d.): "What is the Mises Institute?", at: https://mises.org/about-mises/ what-is-the-mises-Institute (Last access 23.09.2020).

Morresi, Sergio (2008): La nueva derecha argentina y la democracia sin política, Los Polverines: Universidad Nacional De General Sarmiento; Buenos Aires: Biblioteca Nacional.

Nishimura, Katia (2004): "Conservadorismo social: opiniões e atitudes no contexto da eleição de 2002”, in: Opinião Pública, 10, 2, 339-367.

Nobre, Marcos (2013): Imobilismo em movimento: da abertura democrática ao governo Dilma, São Paulo: Companhia das Letras.

Novo (n.d.): "Conheça o Novo", at: https://novo.org.br/novo/conheca/ (Last access 23.09.2020).

Paiva, Denise; Braga, Maria do Socorro S., and Pimentel, Jairo (2007): "Eleitorado e partidos políticos no Brasil”, in: Opinião Pública, 13, 2, 388-408.

Pariser, Eli. (2011), The Filter Bubble: How the New Personalized Web is Changing What We Read and How We Think, London: Penguin.

Pires, Carol (2010): "Em carta, Dilma assina compromisso contra o aborto", in: O Estado de São Paulo, São Paulo, October 15, at: https://politica.estadao.com. br/noticias/geral,em-carta-dilma-assina-compromisso-contra-o-aborto,625257 (Last access 17.09.2020).

Polletta, Francesca and Jasper, James M. (2011): "Collective Identity and Social Movements", in: Annual Review of Sociology, 27, 1, 283-305. 
Power, Timothy (2010): Political Right in Postauthoritarian Brazil: Elites, Institutions, and Democratization, Pennsylvania: Penn State University Press.

Ramírez, Hernán (2007): Corporaciones en el poder: institutos económicos y acción política en Brasil y Argentina: Ipes, Fiel y Fundación Mediterránea, Buenos: Lengua Claro Editora.

Rocha, Camila (2017): "O papel dos think tanks pró-mercado na difusão do neoliberalismo no Brasil", in: Millcayac - Revista Digital de Ciencias Sociales, 4, 7, 95-120, at: http://revistas.uncu.edu.ar/ojs/index.php/millca-digital/article/ view/1020 (Last access 09.08.2020).

(2019): "Menos Marx, mais Mises": uma gênese da nova direita brasileira (Doctoral thesis), São Paulo: Faculdade de Filosofia, Ciências e Letras da Universidade de São Paulo.

Rocha, Camila and Medeiros, Jonas (2020): “Vão todos tomar no...': a política de choque e a esfera pública", in: Horizontes ao Sul, at: https://www.horizontesaosul. com/single-post/2020/04/27/VAO-TODOS-TOMAR-NO-A-POLITICA-DOCHOQUE-E-A-ESFERA-PUBLICA (Last access 09.08.2020).

Rossi, Marina (2015): "Perfil de quem foi à Paulista destoa de lideranças e não poupa ninguém", in: El País, August 18, São Paulo, at: https://brasil.elpais. com/brasil/2015/08/18/politica/1439928655 412897.html (Last access 18.09.2020).

Scruton, Roger (2015): Como ser um conservador, São Paulo: Editora Record.

Senado Federal (2006a): "Projeto de Lei da Câmara n. 37", at: https://www25.senado. leg.br/web/atividade/materias/-/materia/77244 (Last access 23.09.2020).

(2006b): "Projeto de Lei da Câmara n. 122", at: https://www25.senado.leg.br/ web/atividade/materias/-/materia/79604 (Last access 23.09.2020).

Shalders, André (2017): "Como o discurso de Bolsonaro mudou ao longo de 27 anos na câmara?", in: BBC News Brasil, São Paulo, December 7, at: https://www. bbc.com/portuguese/brasil-42231485 (Last access 11.09.2020).

Singer, André (2012): Os sentidos do lulismo: reforma gradual e pacto conservador, São Paulo: Companhia das Letras.

(2018): O lulismo em crise: um quebra-cabeça do período Dilma (2011-2016), São Paulo: Companhia das Letras. 
Soares, Wellington (2015): "Conheça o 'kit gay' vetado pelo governo federal em 2011", Nova Escola, São Paulo, February 1, at: https://novaescola.org.br/ conteudo/84/conheca-o-kit-gay-vetado-pelo-governo-federal-em-2011 (Last access 11.09.2020).

Spohr, Martina (2012): "O empresariado e as relações Brasil-Estados Unidos no caminho do Golpe de 1964", in: Confluenze. Rivista Di Studi Iberoamericani, 4, 2, 45-62.

Stedman Jones, Daniel (2014): Masters of the Universe: Hayek, Friedman, and the Birth of Neoliberal Politics, Princeton: Princeton University Press.

Sunstein, Cass (2017): \#Republic, Princeton: Princeton University Press.

Teitelbaum, Benjamin (2020): War for Eternity: Inside Bannon's Far-Right Circle of Global Power Brokers, London: HarperCollins.

Telles, Helcimara (2016): "ADireita Vai às Ruas: o antipetismo, a corrupção e democracia nos protestos antigoverno", in: Ponto-e-Vírgula: Revista de Ciências Sociais, $19,97-125$.

Thimsen, A. Freya (2017): "Did the Trumpian Counterpublic Dissent Against the Dominant Model of Campaign Finance?", in: Javnost-The Public, 24, 3, 267283.

Venturi, Gustavo (2006): "A opinião pública diante da crise", in: Teoria e Debate, 66, 20-26.

Warner, Michael (2002): "Publics and Counterpublics", in: Public Culture, 14, 1, 4990. 


\section{Working Papers published since 2017:}

1. Maria Sybilla Merian International Centre for Advanced Studies in the Humanities and Social Sciences Conviviality-Inequality in Latin America (Mecila) (2017): "Conviviality in Unequal Societies: Perspectives from Latin America: Thematic Scope and Preliminary Research Programme".

2. Müller, Gesine (2018): "Conviviality in (Post)Colonial Societies: Caribbean Literature in the Nineteenth Century".

3. Adloff, Frank (2018): "Practices of Conviviality and the Social and Political Theory of Convivialism".

4. Montero, Paula (2018): "Syncretism and Pluralism in the Configuration of Religious Diversity in Brazil”.

5. Appadurai, Arjun (2018): "The Risks of Dialogue".

6. Inuca Lechón, José Benjamín (2018): "Llaktapura sumak kawsay / Vida plena entre pueblos. Un concepto emancipatorio de las nacionalidades del Ecuador".

7. Wade, Peter (2018): "Mestizaje and Conviviality in Brazil, Colombia and Mexico".

8. Graubart, Karen (2018): "Imperial Conviviality: What Medieval Spanish Legal Practice Can Teach Us about Colonial Latin America".

9. Gutiérrez, Felipe Castro (2018): "La violencia rutinaria y los límites de la convivencia en una sociedad colonial".

10. Wasser, Nicolas (2018): "The Affects of Conviviality-Inequality in Female Domestic Labour".

11. Segura, Ramiro (2019): "Convivialidad en ciudades latinoamericanas. Un ensayo bibliográfico desde la antropología".

12. Scarato, Luciane (2019): "Conviviality through Time in Brazil, Mexico, Peru, and Río de la Plata".

13. Barreneche, Osvaldo (2019): "Conviviality, Diversidad, Fraternidad. Conceptos en diálogo".

14. Heil, Tilmann (2019): "Conviviality on the Brink".

15. Manzi, Maya (2019): "Fighting against or Coexisting with Drought? Conviviality, Inequality and Peasant Mobility in Northeast Brazil".

16. Guiteras Mombiola, Anna (2019): "School Centres for 'Savages': In Pursuit of a Convivial Sociability in the Bolivian Amazon". 
17. Costa, Sérgio (2019): "The Neglected Nexus between Conviviality and Inequality".

18. Banzato, Guillermo (2019): "Soberanía del conocimiento para superar inequidades. Políticas de Acceso Abierto para revistas científicas en América Latina".

19. Gil Montero, Raquel and Albiez, Sarah (2019): "Conviviality as a Tool for Creating Networks: The Case of an Early Modern Global Peasant Traveler".

20. Briones, Claudia (2019): "Políticas contemporáneas de convivialidad. Aportes desde los pueblos originarios de América Latina".

21. Rojas Scheffer, Raquel (2020): “Articulating Differences and Inequalities: Paid Domestic Workers' and Housewives' Struggles for Rights in Uruguay and Paraguay".

22. Potthast, Barbara (2020): "Mestizaje and Conviviality in Paraguay".

23. Mahile, Alejandra (2020): “¿Legados prestigiosos? La revalorización del sustrato cultural indígena en la construcción identitaria argentina,entre fines del siglo XIX y los años treinta".

24. Segsfeld, Julia von (2020): "Ancestral Knowledges and the Ecuadorian Knowledge Society".

25. Baldraia, Fernando (2020): "Epistemologies for Conviviality, or Zumbification".

26. Feltran, Gabriel (2020): "Marginal Conviviality: On Inequalities and Violence Reproduction".

27. Rojas Scheffer, Raquel (2020): "Physically Close, Socially Distant: Paid Domestic Work and (Dis-)Encounters in Latin America's Private Households".

28. Gil Montero, Raquel (2020): "Esclavitud, servidumbre y libertad en Charcas".

29. Manzi, Maya (2020): "More-Than-Human Conviviality-Inequality in Latin America".

30. Klengel, Susanne (2020): "Pandemic Avant-Garde: Urban Coexistence in Mário de Andrade's Pauliceia Desvairada (1922) After the Spanish Flu”.

31. Gomes, Nilma L. (2021): "Antiracism in Times of Uncertainty: The Brazilian Black Movement and Emancipatory Knowledges".

32. Rocha, Camila (2021): "The New Brazilian Right and the Public Sphere". 

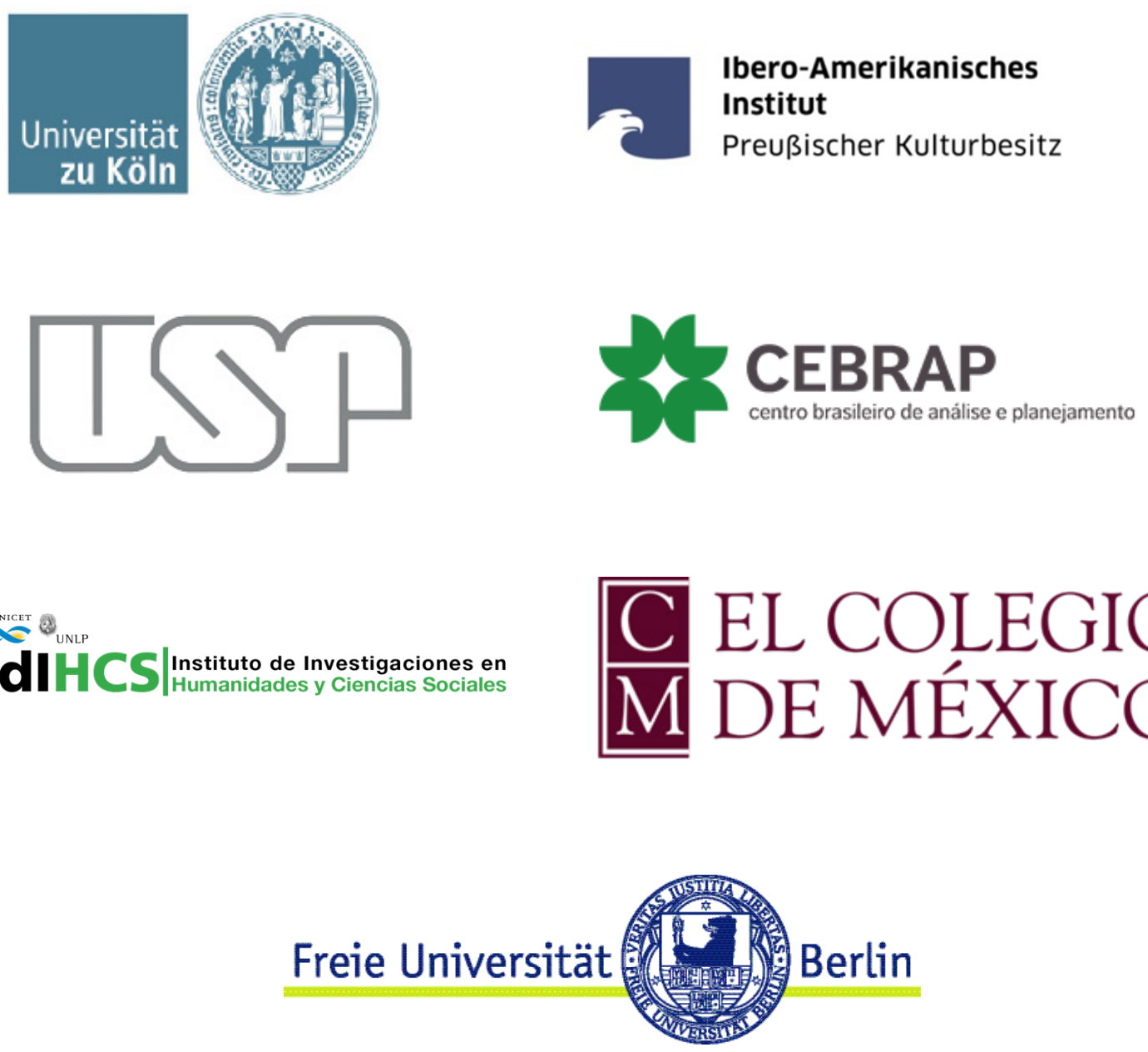

The Maria Sibylla Merian International Centre for Advanced Studies in the Humanities and Social Sciences Conviviality-Inequality in Latin America (Mecila) was founded in April 2017 by three German and four Latin American partner institutions and is funded by the German Federal Ministry of Education and Research (BMBF). The participating researchers investigate coexistence in unequal societies from an interdisciplinary and global perspective. The following institutions are involved: Freie Universität Berlin, Ibero-Amerikanisches Institut/ Stiftung Preußischer Kulturbesitz, Universität zu Köln, Universidade de São Paulo (USP), Centro Brasileiro de Análise e Planejamento (CEBRAP), IdIHCS (CONICET/Universidad Nacional de La Plata), and El Colegio de México. Further information at http://www.mecila.net. 


\section{Contact}

Coordination Office

Maria Sybilla Merian International Centre

for Advanced Studies in the Humanities and

Social Sciences

SPONSORED BY THE

Conviviality-Inequality in Latin America

Rua Morgado de Mateus, 615

São Paulo - SP

CEP 04015-051

Brazil

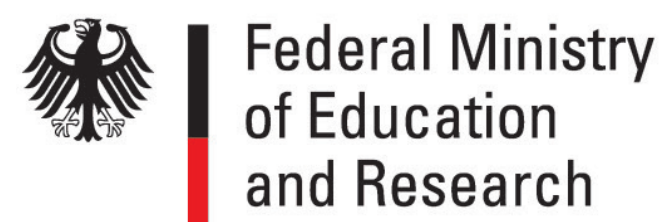

mecila@cebrap.org.br 